DOI: 10.20472/AHC.2018.004.001

\author{
AKIHIRO ABE \\ Iwate Prefectural University, Japan
}

\title{
AN ATTEMPT TO CREATE NEW VALUE AT OPEN-AIR MUSEUMS IN JAPAN: USE OF WEARABLE DEVICES
}

\begin{abstract}
:
In recent years, the business conditions of museums in Japan have been growing increasingly severe as attendance falls and the local governments that operate them are forced to cut budgets. The same is true of open-air museums, which also face the additional pressure of maintenance and management costs for their vast sites and buildings. For this reason, there are reports from across Japan of attempts to increase numbers of visitors at such museums by making them more attractive as tourism resources, by stressing hospitality or strengthening ties with the local community. It is thought that one effective means of overcoming these challenges faced by open-air museums would be through enhancement of information services, which encourage the understanding of and connections with various stakeholders. This study attempted to create new services using wearable devices in order to improve hospitality at open-air museums located on vast sites on hilly land. We implemented an action research approach to gather knowledge on solutions to problems faced in the field, by intervening in activities on site at two open-air museums in Japan. Providing information to support visitors' tours of the museums, integrated with physical information and spatial information, added new value to existing smartphone-based systems intended to support visitors by explaining museum exhibits. Through experiments in the field by proposing "Physical condition management and barrier-free information provision when viewing cultural heritage" at the Hiraizumi World Heritage Site and a new type of information service characterized by "Fusion of support for viewing works of art and health promotion activities" at an open-air art museum, we elucidated the expected results and issues involved in practical operation.
\end{abstract}

\section{Keywords:}

ICT Service Design, Open-air Museum Management, Action Research 


\section{Introduction}

In recent years, the business conditions of museums in Japan have been growing increasingly severe as attendance falls and the local governments that operate them are forced to cut budgets. The same is true of open-air museums, which also face the additional pressure of maintenance and management costs for their vast sites and buildings. For this reason, there are reports from across Japan of attempts to increase numbers of visitors at such museums by making them more attractive as tourism resources by stressing hospitality or strengthening ties with the local community. While new efforts to treat entire areas as open-air museums and see the history, culture, and nature of individual regions as exhibits themselves, through active participation by local residents in preservation and management in a form resembling the concept that originated in France of the eco museum (as opposed to traditional open-air museums managed by curators) are being conducted energetically, it is true that in not a few cases the passing boom for such initiatives seems to have ended, as they have failed to establish systems for their organized and sustained operation.

It is thought that one effective means of overcoming these challenges faced by openair museums would be through enhancement of information services, which encourage the understanding of and connections with various stakeholders. However, most research from an information-support perspective conducted through now has consisted of theoretical research or technological development conducted in the laboratory, on support for decision-making on acts of tourism and art appreciation through navigation and planning. There have been few interdisciplinary, empirical, and practical studies oriented toward solutions to the actual issues faced by open-air museums in the field. By gathering knowledge regarding adoption of various support systems at multiple open-air museums, we have carried out field studies on the forms of effective information services to lead to increased visitor satisfaction (Abe, 2016) (Abe, 2017).

This study is intended as an attempt to create new value for open-air museums by proposing new information services at such museums through use of wearable devices, which are seeing increasingly widespread use in recent years. Since this study is oriented strongly toward practical research to contribute to solving problems in the field, it takes the form of action research to gather knowledge on solutions to problems faced in the field through the researchers intervening in activities on site. This paper first describes the distinctive properties of open-air museums, then it looks at two open-air museums in Japan's Iwate Prefecture as practical sites in the field, describing the distinguishing features of services using wearable devices. Lastly, it considered the knowledge gained from use of wearable devices at open-air museums. 


\section{Distinctive Properties of Open-air Museums}

In general, open-air museums refer to museums located on vast sites, where materials such as architectural heritage or historical structures have been collected (relocated) and made available for viewing by the public. However, the subjects of open-air museums and the forms of their installations vary widely. Based on previous studies in Japan and around the world that touched on the concept of open-air museums, Ochiai (2009) identified the following four distinctive properties of open-air museums:

1. Rather than referring directly to a museum located out of doors, an open-air museum must have an outdoor exhibition space that involves relocation or reproduction of environmental features.

2. An open-air museum must combine both nature and the humanities, and furthermore it must represent a sublimation of a general museum.

3. At the same time it features an outdoor exhibition space, an open-air museum also must have a core museum.

4. The interior exhibitions of the core museum and the exterior exhibitions must be linked, and the interior exhibitions must be a distillation of the outdoor exhibitions.

Looking at the diverse installation forms of open-air museums, Ochiai also proposes the following three categories: those preserving the original terrain, those involving relocation and collection of the items on exhibition, and those involving restoration and construction. The local preservation type refers to those composed of cultural assets such as monuments, historic sites, and early-modern monuments, in addition to natural assets, such as cultural scenery, natural World Heritage Sites, and geoparks, that are managed on location. The relocation/collection type refers to museums built around a specific theme. Items are moved from their original location to another location to exhibit them. The Skansen Museum in Sweden, which relocated architecture, such as traditional homes, to preserve and show it to the public, is representative of this type. Unlike the above two examples, the restored/constructed type refers to museums having outdoor exhibits that are composed mainly of restored or newly constructed items. The distinctive properties and categories of open-air museums in this study will be based on the above definitions.

In an open-air museum, the site where visitors view the exhibits is located on a vast site on hilly land. For this reason, not only is it not easy for people with disabilities, the elderly, and those with young children to view the exhibits, but also it must be said that the physical burden of viewing the exhibits is heavy for most visitors. Since open-air museums serve roles in preservation of historical structures, landscapes, and terrain, it 
is difficult to make them completely barrier free in physical terms, as can be done with an indoor museum. However, it goes without saying that in the future open-air museums, like other facilities, will face demands to cater more to diverse visitors, and it is expected that they will enhance related support through information services (Abe, 2017).

\section{Information Service Design Using Wearable Devices}

\section{Action Research and Human-Centered Design}

First proposed by the psychologist Lewin (1946), the concept of action research has advanced through use in a wide range of interdisciplinary research activities involving social practice. Reports on action research intended to collect and utilize information gained through the adoption process of development, evaluation, and operation of information systems first began to appear during the 1990s, and they have increased steadily since the 2000. Our laboratory conducts education and research aiming to create solutions and new services through information systems for community issues, through integrated advancement of practical research through education and action research based on a problem-based learning/project-based learning (PBL) approach. Through now, we have carried out education and research on tour support systems for a number of open-air museums in Iwate Prefecture (Abe, 2017). While it is difficult for students involved as part of PBL activities to participate in multiple cases during their time as students, faculty members are able to intervene in and compare multiple subject fields in continuous and cross-sectional ways by guiding their students. Put another way, they should be able to compare and contrast multiple sites and to compare and contrast the same sites at different points in time.

In design of information services using wearable devices, the human-centered design (HCD) process ISO9241-210 (ISO 2010), which enables participative design (Muller et al., 1993) and has a high degree of affinity with action research, was employed in light of the need to identify system-based solutions grounded in the intents of the museums and the needs, and tour behavior, of museum visitors. The steps of implementing this HCD process are described below.

Understanding and clarification of the state of use (Step 1): Through methods targeting stakeholders including workshops, interviews, and behavioral observation, ascertaining the situations and properties of use of the information services.

Clarification of users' requirements (Step 2): Sorting out visitors' requirements for information provision, based in part on the intentions of tourism agencies on the service operation side.

Development of solutions through design (Step 3): Development of prototypes, giving 
practical form to images of realization, and identifying solutions to technical issues.

Assessment (Step 4): Having stakeholders asses prototypes and repeating improvements by returning to any of the steps from Step 1 through Step 3 as appropriate until systems and services are confirmed to be useful for the solutions intended initially.

\section{Service Design Concept}

This study involved an attempt to create a new service using wearable devices, aiming to improve hospitality at open-air museums located on vast sites on hilly land. By doing so, it adds new value to existing smartphone-based tour support systems intended to describe the exhibits inside the museum. It does so by providing information to support visitors on their tours of the museum, with reference to heartbeat, body temperature, and other information obtained from the wearable devices as well as information calculated based on such data ("physical information" hereinafter) and information on the location surrounding the visitor, such as geographical features, air temperature, and humidity ("spatial information" hereinafter). (Examples of such information provided include prompt recommendations to rest or replenish fluids.) While use of wearable devices has been considered promising in the fields of health, medicine, and welfare, many studies on such devices have considered only systemic and theoretical topics related to the handling of physical information. This study focuses mainly on physical condition management and support for the mobility of museum visitors, which are not included in the category of medical acts, while also keeping in mind the possibility of future linkage with medical and other information.

The basic design of the base system implemented is described below (Kudo et al., 2016) (Abe et al., 2016). Groups of visitors carried multiple wearable devices and one smartphone. They wore wristband wearable devices to collect and store physical information. This information was provided in succession to the smartphone, for reference in deciding on matters such as when to take breaks. In anticipation of other uses such as enabling caregivers to ascertain the physical conditions of multiple elderly patients using smartphones, this system makes it possible to manage multiple wearers' wearable devices using a single smartphone. The wearable device chosen for this study was Epson's Pulsense, in consideration of factors such as the relative ease of connecting to smartphones, the fact that it is water resistant to three ATMs and thus would present no problems being used outdoors, and the fact that it can be used over a long period of time. An Android smartphone was used. The wearable devices connected with the smartphone via Bluetooth, and physical information collected was transmitted every five seconds via the Device Web API Consortium's GotAPI (Device WebAPI Consortium, 2015). GotAPI is an open-source framework that uses an HTTP server running on the smartphone, called the GotAPI Server, for REST-based interaction with a Web browser or native apps. 


\section{Field Experiments}

Creation of new information services using wearable devices was attempted in the fields of the World Heritage Site in the town of Hiraizumi (type of open-air museum: one preserving the original terrain) and the Ishigami-no-oka Museum of Art in the town of Iwate (type of open-air museum: restoration and construction). Both of these field sites already had adopted visitor support systems using smartphones (Abe, 2013) (Sato et al., 2014).

\section{Case Study 1: Hiraizumi World Heritage Site}

The UNESCO International Charter for the Conservation and Restoration of Monuments and Sites (ICOMOS), revised in 1999 (ICOMOS, 1999), clearly regards preservation of heritage and tourism promotion not as rivals but as two parts of a sustainable relationship between preservation of heritage and cultural tourism, through means such as provision of opportunities for understanding of heritage, returning gains to the local community, and promoting tourism programs through the participation of local residents. At the same time, tourism sites are focusing increasingly on the concept of accessible tourism (Buhalis, Darcy, 2008), by employing consideration for a diverse range of tourists including the elderly and people with disabilities as well as visitors from overseas. Background factors include the fact that travel has come to be recognized, both internationally and domestically, as a right of all people, the aging of Japanese society, increasing diversity among tourists, and efforts to attract travelers in small groups and those from overseas. Based on this context, "Hiraizumi - Temples, Gardens and Archaeological Sites Representing the Buddhist Pure Land," added to the World Heritage List in 2011, had worked to develop an accessible tourist site since even before its addition to the list. Chusonji, the central asset of this World Heritage Site, is located on a hill approximately $130 \mathrm{~m}$ in elevation, and the approach to the temple, about $1 \mathrm{~km}$ in length, involves some steep slopes. The grounds include numerous temples and treasure houses, and it would take about two hours to make the rounds of them all. As such, this was a site faced with challenges with regard to how to provide barrier-free information effectively (Abe, 2013).

Using the basic system, we implemented a prototype for timely provision of barrier-free information (such as the locations of nearby barrier-free restrooms and rest areas and the routes to them) linked to the smartphone app that explains the cultural heritage sites, while also ascertaining physical information and promptly encouraging actions such as taking a break or replenishing fluids. We also had more than 50 users experience this information service and implemented repeated user evaluations and improvements. 


\section{Case Study 2: Ishigami-no-oka Museum of Art}

The Ishigami-no-oka Museum of Art in the town of Iwate is an open-air art museum that also serves as a highway rest area, combining indoor facilities with vast outdoor exhibitions. As a base for artistic and cultural activities rooted in the local community, it aims to be an open art museum where a wide range of generations, from young children through the elderly, can feel welcome at any time, to experience the art up close. Generally, visitors to the art museum come via the rest stop. The museum features interior exhibitions as well as permanent exterior exhibitions on its 16-hectare site, consisting mainly of 17 works of sculpture. In 2015, the exterior exhibitions were named a "Forest Therapy Site," as an area whose relaxation effects were recognized by experts from the field of forestry science (certifying agency: Forest Therapy Society). A Forest Therapy ${ }^{\circledR}$ Site refers to an area that has been demonstrated scientifically to have healing effects and includes multiple facilities that contribute to a Therapy Road@ and to health improvement (Forest Therapy Society, 2008). Five courses in the town of Iwate, centered on the outdoor exhibitions of the Ishigami-no-oka Museum of Art, have been certified as Forest Therapy Roads. As a result, it is seeing increasing use by visitors from a wide range of generations, for purposes including not only art appreciation but also health improvement and recreation, and it is expected to provide informational support in areas other than simply explaining the works of sculpture on exhibit.

Accordingly, we used the basic wearable-device system described above to implement informational services to support walking in the woods, through linkage with the app that explains the works of sculpture (for example, visualization of volumes of physical activity, providing information on places to rest and scenic spots linked to physical information, and explaining plants by season). We also verified the effects of the information service through multiple hands-on workshops for local residents and facility managers (Chiba et al., 2018).

\section{Findings and Discussion}

\section{Functionality of the Proposed Service}

We confirmed the feasibility of collecting and displaying, on a smartphone via Bluetooth, physical information on up to four persons wearing wearable devices, in real time for four hours or longer. The physical information collected was reviewed by a medical practitioner who cooperated in the study, confirming that, in general, the system was able to collect valid figures, although some cases were identified of figures thought to represent device errors. While this experiment used standard values for the heart rate at rest, in practical implementation differences among individuals should be taken into consideration. It is likely that if the wearing of wearable devices were to become commonplace, then it would be possible to collect various types of physical information 
in everyday activities, and information could be provided with greater consideration for matters such as individual physical differences.

\section{Effectiveness of the Proposed Service}

We attempted to analyze, based on log data, the impact of the information service on subjects' heart rates. In both cases, we confirmed a tendency for heart rates to decrease after receipt of information on the smartphone. In other words, it can be considered that transmission of information at an appropriate timing leads, although this relies on the independent judgment of individual users, to an inducement to rest, and this in turn had some effect on lessening visitors' physical burdens. Accordingly, the timing of transmission is important. Still, there remains room for improvement in the algorithms used, since for example there were some cases in which messages encouraging taking a break were not sent in response to rapid increases in heart rate, which had not been anticipated during the design process.

Results from the provision of barrier-free information in Case 1 suggested that it led to a greater sense of reassurance among caregivers (volunteers other than family members who accompanied subjects), not just museum visitors, by enabling provision of such information while ascertaining the subjects' physical condition. In Case 2, it can be expected that such information could have the effect of increasing repeat visits by local residents, through adaptation to increasing diversity in reasons for visiting openair museums.

\section{Utility Value of Big Data Collected}

It is likely that the physical information and spatial information collected through visitors' use of the information services can be put to use in improving hospitality in open-air museum spaces. For example, to develop more accessible tourism facilities in Case 1, locations could be identified such as those where heart rates tended to exceed their base levels or where visitors frequently took breaks, and benches could be installed or alternative routes could be set up to lessen the burden on visitors as they tour the facility. In addition, in Case 2, the ability to ascertain emotional changes such as relaxation from changes in heart rates should make it possible to identify locations and routes that contribute to relaxation, and to provide such information to visitors. Efforts such as these could lead to creation of new value for open-air museums.

\section{Conclusion}

This study attempted to create new services using wearable devices in order to improve hospitality at open-air museums located on vast sites on hilly land. In field studies at two open-air museums in Japan, providing information to support visitors' tours of the 
museums, integrated with physical information and spatial information, added new value to existing smartphone-based systems intended to support visitors by explaining museum exhibits. Through experiments in the field by proposing "Physical condition management and barrier-free information provision when viewing cultural heritage" at the World Heritage Site in the town of Hiraizumi and a new type of information service characterized by "Fusion of support for viewing works of art and health promotion activities" at the Ishigami-no-oka Museum of Art in the town of Iwate, we elucidated the expected results and issues involved in practical operation.

Future plans call for verification of the impact of the proposed services through system use over the long term. We also hope to help improve hospitality at open-air museum spaces through use of big data collected through these projects.

\section{References}

ABE, A. (2013). The Role of ICT on Cultural Heritage Tourism: A Case Study, Proc. 2nd International Conference on Economic and Social Development, pp.2-8.

ABE, A. (2016). Case Study on Visit Characteristics of Open-air Museum Information Service Users, Proc. 23th IISES International Academic conference, pp.1-7.

ABE, A., KANO, T. and KUDO, A. (2016). Development and Field Deployment of Reassurance Support System for Universal Tourism, IPSJ SIG Technical Reports, Vol.2016-ASD-6, No.3, pp.1-6.

ABE, A. (2017). Study on Development and Operation of Open-air Museum Visiting Support Systems Using Action Research, Bulletion of Japan Museum Management Academy, No.21, pp.63-69.

BUHALIS, D. and DARCY, S. (2008). Accesible Tourism: Concepts and Issues, Toronto: Channel View Publications.

CHIBA, K., ABE, A., ICHIKAWA, H., TOMIZAWA, H. and KUDO, A. (2018). Development of Open-Air Museum Appreciation Support System Considering Health Promotion by Wearable Devices, Proc. 80th National Convention of IPSJ, 6ZE-02.

Device WebAPI Consortium (2015). GotAPI, Available at http://en.device-webapi.org/ [Accessed 28 Mar. 2018].

Forest Therapy Society (2008). Forest Therapy ${ }^{\circledR}$, Available at http://www.fo-society.jp/ [Accessed 28 Mar. 2018].

ICOMOS (1999). INTERNATIONAL CULTURAL TOURISM CHARTER Managing Tourism at Places of 
Heritage Significance, Available at http://www.icomos.org/charters/tourism_e.pdf [Accessed 28 Mar. 2018].

ISO 9241-210 (2010). Ergonomics of Human-System Interaction - Human-Centred Design for Interactive Systems.

KUDO, A., KANO, T. and ABE, A. (2016). Study on Reassurance Support System Using Wearable Devices, Proc.78th National Convention of IPSJ, 2E-03.

LEWIN, K. (1946). Action Research and Minority Problems, Journal of Social Issues, Vol.2, No.4, pp.3446.

MULLER, M. J., WILDMAN, D. M. and WHITE, E. A. (1993). Participatory Design, Communication of the ACM, Vol.36, No.4, pp.24-28.

OCHIAI, N. (2009). Study of the Open-air Museum, Tokyo: Yuzankaku Inc.

SATO, R., ICHIKAWA, H., TOMIZAWA, H. and ABE, A. (2014). Development of Tourism Support System for the Open-air Museum Adjacent of the Service Station, IPSJ SIG Technical Reports, Vol.2014IS-130, No.2, pp.1-8. 